\title{
English Aspect: L1 Transfer and Explicit Instruction
}

\section{Yuko Koike \\ Fukuoka Prefectural University}

\section{Reference Data:}

Koike, Y. (2019). English aspect: L1 transfer and explicit instruction. In P. Clements, A. Krause, \& P. Bennett (Eds.), Diversity and inclusion. Tokyo: JALT.

Aspect shows cross-linguistic variation, and the role of the first language in the acquisition of aspect is often discussed in second language literature. However, whether L 1 transfer actually occurs in the areas of grammar is controversial. In this paper, I discuss the aspectual characteristics of English and Japanese associated with their aspectual verb classes, which show both similarities and differences between the languages. Japanese learners of English are predicted to have difficulty in associating the form with the meaning and transfer $L 1$ features when learning aspectual properties of English. In order to investigate this prediction, I examine whether the learners transfer the L1 interpretations associated with the verb classes and the aspectual morpheme when learning English aspect. I then discuss effective instruction for teaching aspect and introduce instructional materials designed to be used for Japanese learners of English.

アスペクトには言語特有の特徴が見られ、第二言語習得における母語の影響がしばしば指摘されている。しかしながら、文 法習得において母語の転移が起こるか否については意見の統一が見られていない。本論文は、英語と日本語それぞれの動詞 のアスペクトによる分類に基づく特徴と両言語の類似点及び相違点について述べ、日本語母語話者が英語のアスペクトを学 ぶ際に母語の転移が起こるかについて考察する。さらに、日本語母語話者を対象とした英語のアスペクトの効果的な指導方 法を考察しその教材を紹介する。

$\sim$ he role of the L1 is often discussed in L2 acquisition. However, whether L1 transfer 1 actually occurs in the areas of grammar is controversial. Nevertheless, aspect shows cross-linguistic variation, and L1 transfer has been reported in the acquisition of aspect in L2 English (Gabriele, Maekawa, \& Banon, 2008; Gabriele, Martohardjono, \& McClure,
2003), L2 Japanese (Nishi \& Shirai, 2007; Sugaya \& Shirai, 2007), and L2 Spanish (Montrul \& Slabakova, 2003; Gabriele, Banon, Prego, \& Canales, 2015). It has also been argued that lexical aspect influences the acquisition of tense-aspect morphology (Andersen, 1991; Bardovi-Harlig, 2000; Shirai \& Kurono, 1998).

The purpose of the present study was to investigate whether Japanese learners of English transfer aspectual semantics from their $\mathrm{L} 1$ and to examine effective instruction. I first discuss the aspectual characteristics of English and Japanese and then describe an experiment to examine the L1 transfer of aspectual semantics. Specifically, I examine whether learners transfer the $\mathrm{L} 1$ interpretations associated with the verb classes and the aspectual morpheme. Furthermore, I discuss effective instruction for teaching aspect and introduce instructional materials designed to be used with Japanese learners of English.

\section{Verbal Aspect in English and Japanese}

Aspectual Classes of English Verbs

Aspect is defined as a grammatical category that marks the duration or type of temporal activity denoted by the verb (e.g., perfect and imperfect) and is distinguished from tense, which expresses the time of a situation described in a proposition relative to some other time (e.g., present, past, and future; Crystal, 1994). Aspect is determined compositionally by properties of the verb together with the verb's arguments and adjuncts (Verkuyl, 1972). Moreover, differences in the inherent semantic differences in verbs lead to different interpretations when they are combined with aspect markers (Dowty, 1979).

The inherent lexical meanings of English verbs generally refer to Vendler's (1957) verb classification, which distinguished four distinct aspectual classes of English verbs or verb phrases: states, activities, accomplishments, and achievements, based on their inherent temporal properties: 


\section{Classes}

States:

Activities:

Accomplishments:

Achievements:

\section{Examples}

know, love, believe, want, have

run, walk, swim, push, pull

paint a picture, make a chair, build a house, write a letter, draw a circle

recognize, realize, notice, identify, find

Furthermore, the inherent meanings of verbs reflect their distinct structural patterns, which are shown in the following examples taken from Vendler (1957) and Dowty (1979), with some modifications:

(1) a. *John is knowing the answer. (state)

b. John is running. (activity)

c. John is painting a picture. (accomplishment)

d. *John is recognizing her. (achievement)

(* = ungrammatical)

States are not dynamic, and achievements imply no duration; therefore, they do not occur in the progressive. It should be noted that achievements can occur with the -ing form (e.g., He is dying; The airplane is arriving.); however, they do not have a progressive meaning but mean a preliminary stage, that is, implying reaching an end point.

\section{Aspectual Classes of Japanese Verbs}

Kindaichi (1950) similarly proposed four aspectual classes of Japanese verbs: stative (jotai doshi), continuative (keizoku doshi), instantaneous (shunkan doshi), and Type Four (dai yon-shu no doshi):

\section{Classes}

Stative

Continuative

Instantaneous

Type Four

\section{Examples}

aru (be), iru (need), dekiru (can do), mieru (be visible) yотu (read), kaku (write), hashiru (run), oyogu (swim) kizuku (notice), tsuku (light up), shinu (die), aku (open) sugureru (be excellent), arifureru (be common), zubanukeru (be outstanding), bakageru (be absurd)

In terms of semantic properties, stative and Type Four classes correspond to Vendler's (1957) states, continuative corresponds to Vendler's activities, and instantaneous corresponds to Vendler's achievements. The difference between stative and Type Four is their structural patterns; stative verbs cannot occur with the -te iru form, whereas Type Four verbs must always occur with the -te iru form (e.g., Kare wa okane ga aru/"at-te iru [He has (a lot of) money], Kare wa *sugureru / sugure-te iru [He is excellent]).

This classification is also based on the semantic characteristics of verbs with the aspectual morpheme -te iru. The morpheme -te iru partly corresponds to the English morpheme -ing. However, English and Japanese verb classes show both similar and different patterns with the morphemes -ing and -te iru respectively.

\section{Similarities and Differences of English and Japanese Verbal Aspect}

As discussed above, English and Japanese verb classes show both similarities and differences:

(2) a. *Kare-wa okane-ga at-te iru. (stative) he-TOP money-NOM be-TE IRU

*He is having money.

b. Kare-wa shinbun-o yon-de iru. (continuative) he-TOP newspaper-ACC read-TE IRU-

He is reading a newspaper.

c. Kare-wa kizui-te iru. (instantaneous)

he-TOP notice-TE IRU

He is aware of it.

d. Kare-wa sugure-te iru. (Type 4)

he-TOP be excellent-TE IRU

He is excellent.

$(*$ ungrammatical)

Like states in English, Japanese stative verbs do not occur in the -te iru construction, and like activities in English, continuous verbs have a progressive meaning with the -te iru form. However, unlike achievements in English, instantaneous verbs do not mean a preliminary stage but have a resultative state meaning. As shown in the example (2)c, the 
verb kizuku (notice) in the -te iru construction (kizui-te iru (be aware of)) has a resultative state meaning. As discussed earlier, Type Four verbs semantically correspond to states in English, but they must always appear in the -te iru construction. Figure 1 shows the comparison of Vendler's (1957) English verb classes and Kindaichi's (1950) Japanese verb classes in terms of semantic and structural properties.

\begin{tabular}{llll}
\hline English verb classes & -ing & Japanese verb classes & -te iru \\
\hline States & $\mathrm{X}$ & $\begin{array}{l}\text { Stative } \\
\text { Type Four }\end{array}$ & $\begin{array}{l}\mathrm{X} \\
\text { stative }\end{array}$ \\
\hline $\begin{array}{l}\text { Activities } \\
\text { Accomplishments }\end{array}$ & progressive & Continuative & progressive \\
\hline Achievements & preliminary stage & Instantaneous & resultative state \\
\hline
\end{tabular}

Figure 1. Comparison of English and Japanese verb classes; $\mathrm{X}=$ ungrammatical

It should also be noted that Japanese continuative and instantaneous verbs in the -te iru construction can express experiential state as well, which is distinct from resultative state. The former typically occurs with an adverbial indicating a completed event such as ichi-do (once) and kyonen (last year); the latter occurs with an adverbial such as ima (now) and mada (still) (Ogihara, 1998), as shown in the following examples:

he-TOP now movie-ACC

watch-TE IRU

He is watching a movie now.

(progressive)

b. Kare-wa 3-do kono eiga-o mi-te iru.

he-TOP 3 times this movie-ACC watch-TE IRU

He has watched this movie three times. (experiential state)

c. Kare-wa ima kekkon shi-te iru.

he-TOP now marry-TE IRU

He is married now.

(resultative state)

d. Kare-wa 2-do kekkon shi-te iru. he-TOP 2 times marry-TE IRU He has been married two times.
In the -te iru construction, the Japanese continuative verb miru (watch) can have an experiential state meaning in addition to a progressive meaning. Also, the instantaneous verb kekkon suru (marry) can have an experiential state and a resultative state meaning; not only verb classes but also adjuncts such as adverbials affect interpretation.

\section{The Present Study}

The comparison of English and Japanese aspectual verb classes shows cross-linguistic variation. There are both similarities and differences in lexical, syntactic, and semantic properties between the two languages. Although lexical properties of verb classes are similar, some differences are observed, especially in their semantic properties. Therefore, Japanese learners of English are predicted to have difficulty in associating the form with the meaning and transfer L1 features in learning aspectual properties of English.

Therefore, the purpose of the present study is to investigate the following research questions:

RQ1. Do Japanese learners of English transfer aspectual semantics from their L1?

RQ2. In particular, do learners transfer the L1 interpretations associated with the verb classes and the aspectual morpheme?

\section{Participants}

Ninety-eight native speakers of Japanese participated in the study. These participants (mean age: 19) were undergraduate students taking a general English course at a university in Japan. Their CEFR levels of English were A2-B1.

\section{Sentence Selection Task}

Participants completed a sentence selection task designed to measure knowledge of English aspect and transfer from their native language. The participants read eight Japanese sentences in the -te instruction and their English translations, each of which had a gap. The participants were asked to choose the best verb form for each gap from four choices. Each of the Japanese sentences takes a progressive, resultative state, or experiential state reading, depending on its aspectual verb class and/or adverbials. The Japanese verbs and their aspectual classes used in the task were as follows:

- Continuative: aruku (walk), nemuru (sleep) (†Activity) 

order.

- Continuative: hondana o tsukuru (make a bookshelf), tegami o kaku (write a letter), kono eiga o miru (watch this movie), marason o hashiru (run a marathon) (†Accomplishment)

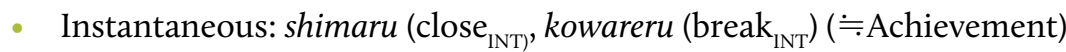

The target test sentences are shown in Figure 2. The sentences were given in random

\section{No Japanese sentence}

1 Kare-wa ima arui-te iru. he-TOP now walk-TE IRU

English equivalent \& four choices

Aspect

$\mathrm{He}$

walks is walking is walked

has walked

2 Akachan-wa ima nemut-te iru. The baby baby-TOP now sleep-TE IRU sleeps is sleeping is slept has slept

3 Kare-wa ima hondana-o tsukut-te iru. make-TE IRU

4 Kanojo-wa ima tegami-o she-TOP now letter-ACC

kai-te iru.

$\mathrm{He}$ a bookshelf. progressive makes is making is made has made

She a letter.

writes is writing is written has written write-TE IRU

5 Doa-ga ima shimat-te iru. The door door-NOM now close-TE IRU closes is closing is closed has closed

6 Kikai-ga ima machine-NOM now koware-te iru. The machine breaks is breaking is broken has broken

resultative state

resultative state he-TOP now bookshelf-ACC

\begin{tabular}{|c|c|c|c|}
\hline No & Japanese sentence & $\begin{array}{l}\text { English equivalent \& four } \\
\text { choices }\end{array}$ & Aspect \\
\hline 7 & $\begin{array}{ll}\text { Watashi-wa } & \text { kono eiga-o } \\
\text { I-TOP } & \text { this movie-ACC } \\
\text { nandomo } & \text { mi-te iru. } \\
\text { many times } & \text { watch-TE IRU }\end{array}$ & $\begin{array}{l}\text { I___ this movie } \\
\text { many times. } \\
\text { watch am watching } \\
\text { am watched have watched }\end{array}$ & $\begin{array}{l}\text { experiential } \\
\text { state }\end{array}$ \\
\hline 8 & $\begin{array}{l}\text { Kare-wa } 3 \text {-kai } \\
\text { he-TOP } 3 \text { times } \\
\text { marason-o hashit-te iru. } \\
\text { marathon-ACC run-TE IRU }\end{array}$ & $\begin{array}{l}\text { He } \\
\text { three times. } \\
\text { runs is running is run } \\
\underline{\text { has run }}\end{array}$ & $\begin{array}{l}\text { experiential } \\
\text { state }\end{array}$ \\
\hline
\end{tabular}

Figure 2. Test sentences; correct forms are underlined.

As discussed in the previous sections, Japanese continuative verbs, which correspond to English activities and accomplishments, have a progressive meaning in the -te iru construction. This pattern is similar to that of English activities and accomplishments with -ing. Therefore, for sentences 1-4) no difficulty in choosing the correct form was predicted. On the other hand, Japanese instantaneous verbs, which correspond to English achievements, have a resultative state meaning in the -te iru construction. This interpretation is specific to Japanese. Therefore, it was predicted that the learners would have difficulty choosing the correct form for the sentences 5 and 6 . Moreover, sentences 7 and 8 have an experiential state meaning. This interpretation is also language specific, suggesting that learners would have difficulty choosing the correct form.

\section{Results}

The results of the selection task are shown in Tables 1-4. The participants' break-TE IRU sleep, make a bookshelf, and write a letter) are shown in Table 1. As predicted, most of the participants did not have difficulty choosing a correct verb form for sentences 1-4. More than $90 \%$ of the participants selected the present progressive form for activities and accomplishments.

The participants' interpretations of resultative state aspect for achievements ( 5 and 6) are shown in Tables 1 and 2 . As shown in Table 1, less than $50 \%$ of the participants chose correct forms for the resultative state aspect for achievements. Table 2 shows the interpretations of progressive aspect for English activities and accomplishments (walk, 
participants' incorrect choices. Of the participants, 20 to $30 \%$ incorrectly selected the present progressive form.

Table 1. Correct Choices for Progressive \& Resultative State Interpretation $(N=98)$

\begin{tabular}{llll}
\hline Verb class & Verb / Verb phrase & Correct form & Number \\
\hline Activity & walk & He is walking. & $97(99 \%)$ \\
& sleep & The baby is sleeping. & $91(93 \%)$ \\
Accomplishment & make a bookshelf & He is making a bookshelf. & $93(95 \%)$ \\
& write a letter & She is writing a letter. & $96(98 \%)$ \\
\multirow{2}{*}{ Achievement } & close & The door is closed. & $43(44 \%)$ \\
& break & The machine is broken. & $47(48 \%)$ \\
\hline
\end{tabular}

Table 2. Incorrect Choices for Resultative State Interpretation $(N=98)$

\begin{tabular}{llll}
\hline Verb class & Verb / Verb phrase & Incorrect form & Number \\
\hline Achievement & close & The door closes. & $15(15 \%)$ \\
& & The door is closing. & $26(27 \%)$ \\
& The door has closed. & $14(14 \%)$ \\
\multirow{2}{*}{ break } & The machine breaks. & $10(10 \%)$ \\
& The machine is breaking. & $21(21 \%)$ \\
& The machine has broken. & $20(20 \%)$ \\
\hline
\end{tabular}

Tables 3 and 4 show the participants' interpretations of experiential state aspect. As shown in Table 3, approximately $80 \%$ of the participants correctly selected present perfect forms. Incorrect choices are listed in Table 4. A small number of participants chose present and present progressive forms.
Table 3. Correct Choices for Experiential State Interpretation $(N=98)$

\begin{tabular}{lllll}
\hline Verb class & $\begin{array}{l}\text { Verb / } \\
\text { Verb phrase }\end{array}$ & Adverbial & Correct form & Number \\
\hline Accomplishment & $\begin{array}{l}\text { watch this } \\
\text { movie } \\
\text { run a marathon }\end{array}$ & many times & $\begin{array}{l}\text { I have watched this } \\
\text { movie many times. }\end{array}$ & 77 (79\%) \\
& & $\begin{array}{l}\text { He has run a marathon } \\
\text { three times. }\end{array}$ & $78(80 \%)$ \\
\hline
\end{tabular}

Table 4. Incorrect Choices for Experiential State Interpretation ( $N=98)$

\begin{tabular}{|c|c|c|c|c|}
\hline Verb class & $\begin{array}{l}\text { Verb / } \\
\text { Verb phrase }\end{array}$ & Adverbial & Incorrect form & Number \\
\hline \multirow[t]{6}{*}{ Accomplishment } & $\begin{array}{l}\text { watch this } \\
\text { movie }\end{array}$ & many times & $\begin{array}{l}\text { I watch this movie many } \\
\text { times. }\end{array}$ & $13(13 \%)$ \\
\hline & & & $\begin{array}{l}\text { I am watching this movie } \\
\text { many times. }\end{array}$ & $7(7 \%)$ \\
\hline & & & $\begin{array}{l}\text { I am watched this movie } \\
\text { many times. }\end{array}$ & $1(1 \%)$ \\
\hline & run a marathon & three times & $\begin{array}{l}\text { He runs a marathon } \\
\text { three times. }\end{array}$ & $14(14 \%)$ \\
\hline & & & $\begin{array}{l}\text { He is running a } \\
\text { marathon three times. }\end{array}$ & $5(5 \%)$ \\
\hline & & & No response & $1(1 \%)$ \\
\hline
\end{tabular}

\section{Discussion}

The participants' selection of verb forms show that for activities and accomplishments (walk, sleep, make a bookshelf, write a letter), most selected the correct verb forms. They accepted activities and accomplishments with the -ing form to express an ongoing progressive aspect. This result was predicted because Japanese continuative verbs correspond semantically to English activities or accomplishments, and both occur with the aspectual morphemes -te iru and -ing respectively to express a progressive aspect. 
On the other hand, for achievements (close, break), the number of correct answers decreased. As discussed above, Japanese instantaneous verbs, which correspond to English achievements, have a resultative state meaning in the -te iru construction. However, English achievements with the -ing form express a preliminary stage implying reaching an end point. Therefore, Japanese learners of English were predicted to have difficulty in selecting a correct form for achievements.

Gabriele (2009) postulated that Japanese learners of English need to rule out a resultative state interpretation for achievements with the -ing form. Other studies have reported that ruling out interpretations that are available in the L1 but not in the $\mathrm{L} 2$ is a challenge for L2 learners (Gabriele et al., 2015; Hirakawa, 2001). In the interpretation task conducted by Gabriele it was also found that Japanese learners of English allowed achievements with -ing form to refer to completed aspect.

In the present study, resultative state aspect for English achievements (close, break) is expressed in passive forms (the door is closed; the machine is broken). Less than $50 \%$ of the participants correctly selected these forms whereas less than 30\% incorrectly chose achievements with the -ing form (the door is closing; the machine is breaking) to refer to resultative state aspect. These results seem to indicate the transfer of $\mathrm{L} 1$ interpretation wherein resultative state aspect is expressed in the -te iru construction in Japanese.

The results can also be due to universal difficulty. The aspect hypothesis (Andersen \& Shirai, 1994) suggests that the inherent semantic aspects of verbs affect early language learners in their acquisition of tense-aspect markers. In other words, progressive morphology is strongly associated with activities. Thus, it may also be possible that the learners overextended the use of the progressive to other verb classes.

As discussed in the previous section, experiential state interpretation occurs in the -te iru construction generally with an adverbial such as ichido (once) and kyonen (last year). This interpretation is available with both continuous and instantaneous verbs. The results of the present study show that approximately $80 \%$ of the participants correctly selected perfect forms (have watched, has run). Although the verb class is accomplishment (watch a movie, run a marathon), only a few participants chose the present progressive form -ing. Adverbials such as many times and three times may help learners choose correct verb forms for experiential state aspect. Aspect is determined compositionally by properties of the verb in conjunction with its arguments and adjuncts (Verkuyl, 1972). This result seems to show that adverbials affect learners' choices more than verbs' lexical meanings.

\section{Teaching English Aspect}

As observed above, there are similarities and differences in aspectual patterns between English and Japanese; lexical properties of verb classes are similar whereas some differences are observed in their syntactic and semantic patterns. Lardiere (2009) claimed that L2 learners face difficulty when the L1 and L2 differ in the combination of lexical items and their features. It is, therefore, crucial to understand how learners relate L1 to L2 in their learning processes. Moreover, Schmidt $(2001,2010)$ claimed that attention to the linguistic features that are not available in the L1 may be necessary in second language acquisition. In addition, positive evidence is not always sufficient for $\mathrm{L} 2$ learners to analyze complex grammatical structures (White, 1987). Therefore, L2 learners need the negative evidence that they receive from instruction in order to understand L1L2 differences.

Accordingly, explicit instruction is crucial for $\mathrm{L} 2$ learners to learn aspectual rules and patterns of English. It helps learners to pay attention to L1-L2 differences and master target grammatical structures. In particular, instruction should focus on lexical properties of verb classes and the syntactic and semantic properties associated with their lexical meanings. It should also help learners compare their L1 and L2 and be aware of the differences.

\section{Instructional Materials}

The instructional materials described here are designed for Japanese learners of English to learn the aspectual characteristics of English compared with those of Japanese. They can be used as part of a grammar or writing lesson and especially focus on lexical properties of verb classes and the syntactic and semantic properties associated with their lexical meanings. The aim is for learners to pay attention to and be aware of aspectual differences between the two languages so as to understand and learn English aspect. The materials (see Appendix) consist of eight activities whose goals are for students to learn Japanese and English aspectual verb classes, learn the meaning of -te iru for each Japanese verb class and of -ing for each English verb class, and compare Japanese -te iru and English -ing. The materials use a minimal number of technical terms and basic vocabulary to avoid interfering with comprehension. In addition, for the exercises on Japanese verbs, it is recommended that Japanese be used in the written materials and the teacher explain in Japanese to help the learners' cognitive processes work efficiently. 


\section{Conclusion}

The present study investigated whether Japanese learners of English transfer aspectual semantics from the L1 and proposed instructional activities for teaching English aspect, which are summarized as follows:

1. Aspect shows cross-linguistic variation. There are similarities and differences in aspectual patterns between English and Japanese. The lexical properties of both languages' verb classes are similar; however, some differences are observed in their syntactic and semantic patterns.

2. It was predicted that Japanese learners of English will have difficulty in associating the form with the meaning and transfer $\mathrm{L} 1$ features in learning aspectual properties of English. Therefore, the present study examined whether the learners transferred L1 interpretations associated with the verb classes and the aspectual morpheme when learning English aspect.

3. The results of a sentence selection task targeting resultative state interpretation of achievements suggest that Japanese learners of English transfer L1 interpretations associated with verb classes and the aspectual morpheme. More than half of the participants incorrectly accepted the form associated with the L1 interpretation.

4. It is also possible that the results were due to universal difficulty. It has been argued that progressive morphology is strongly associated with activities in the early stage of language acquisition. The learners may also have overextended the use of the progressive to the achievement class.

5. The results of a sentence selection task targeting experiential state interpretation show that adverbials play a role in helping learners to understand the sentence. Although accomplishment verbs were used in the task, few participants incorrectly selected the progressive form, indicating that adverbials affected the learners' choices more than the verbs' lexical meanings.

6. L2 learners face difficulty in learning linguistic features that are not present in the L1. Therefore, attention to linguistic features and negative evidence received from instruction are necessary to understand L1-L2 differences. Explicit instruction helps learners to pay attention to L1-L2 differences to master the target grammatical structures. In order to learn English aspect, instruction should focus on lexical properties of verb classes and their syntactic and semantic properties associated with their lexical meanings.

The present study suggests the transfer of aspectual semantics of L1 in second language acquisition. In addition, explicit instruction discussed here is applicable to other areas of grammar as well. It is important to help L2 learners to acquire target features through explicit instruction. However, further research is needed to examine the nature of $\mathrm{L} 1$ transfer and universal difficulty as aspect hypothesis.

Bio Data

Yuko Koike is a professor at Fukuoka Prefectural University. She is currently interested in grammar and pronunciation instruction for second language learners. <yukoike@ gmail.com>

\section{References}

Andersen, R. (1991). Developmental sequences: The emergence of aspect marking in second language acquisition. In T. Huebner \& C. Ferguson (Eds.), Crosscurrents in second language acquisition and linguistic theories (pp. 305-324). Amsterdam, the Netherlands: John Benjamins.

Andersen, R., \& Shirai, Y. (1994). Discourse motivations for some cognitive acquisition principles. Studies in Second Language Acquisition, 16(2), 133-156. https://doi.org/10.1017/ s0272263100012845

Bardovi-Harlig, K. (2000). Tense and aspect in second language acquisition: Form, meaning, and use. Oxford, England: Blackwell.

Crystal, D. (1994). An encyclopedic dictionary of language and languages. Cambridge, MA: Blackwell. Dowty, D. (1979). Word meaning and Montague grammar. Dordrecht, Germany: Kluwer.

Gabriele, A. (2009). Transfer and transition in the SLA of aspect. Studies in Second Language Acquisition, 31(3), 371-402. https://doi.org/10.1017/s0272263109090342

Gabriele, A., Banon, J. A., Prego, B. L., \& Canales, A. (2015). Examining the influence of transfer and prototypes on the acquisition of the present progressive in L2 Spanish. In D. Ayoun (Ed), The present tense in second language acquisition (pp.113-151). Amsterdam, the Netherlands: John Benjamins.

Gabriele, A., Maekawa, J., \& Aleman Banon, J. (2008). Can we predict when “dying” will be difficult: Progressive achievements in L2 English. In J. Chandlee et al. (Eds.), BUCLD 33 Proceedings (pp. 175-186). Summerville, MA: Cascadilla Press.

Gabriele, A., Martohardjono, G., \& McClure, W. (2003). Why swimming is just as difficult as dying for Japanese learners of English. ZAS Papers in Linguistics, 29, 85-103.

Hirakawa, M. (2001). L2 acquisition of Japanese unaccusative verbs. Studies in Second Language Acquisition, 23(2), 221-245. https://doi.org/10.1017/s0272263101002054

Kindaichi, H. (1950). 日本語動詞のアスペクト [The aspect of Japanese verbs]. 言語研究 [Language Study], 15, 48-63. 
Lardiere, D. (2009). Further thoughts on parameters and features in second language acquisition: A reply to peer comments on Lardiere's "Some thoughts on the contrastive analysis of features in second language acquisition in SLR 25(2)." Second Language Research, 25(3), 409-422. https://doi. org/10.1177/0267658309104579

Montrul, S., \& Slabakova, R. (2003). Competence similarities between native and near-native speakers. Studies in Second Language Acquisition, 25(3), 351-398. https://doi.org/10.1017/ s0272263103000159

Nishi, Y., \& Shirai, Y. (2007). Where L1 semantic transfer occurs: The significance of cross-linguistic variation in lexical aspect in the $\mathrm{L} 2$ acquisition of aspect. In Y. Matsumoto, D. Y. Oshima, O. Robinson, \& P. Sells (Eds.), Diversity in language: Perspectives and implications (pp. 219-241). Stanford, CA: CSLI Publications.

Ogihara, T. (1998). The ambiguity of the -te iru form in Japanese. Journal of East Asian Linguistics, 7, $8-120$.

Schmidt, R. (2001). Attention. In P. Robinson (Eds.), Cognition and second language instruction (pp. 3-32). Cambridge, England: Cambridge University Press.

Schmidt, R. (2010). Attention, awareness, and individual differences in language learning. In W. M. Chan, S. Chi, K. N. Cin, J. Istanto, M. Nagami, J. W. Sew, T. Suthiwan, \& I. Walker (Eds.), Proceedings of CLaSIC 2010 (pp. 721-737). Singapore: National University of Singapore, Centre for Language Studies.

Shirai, Y., \& Kurono, A. (1998). The acquisition of tense-Aspect marking in Japanese as a second language. Language Learning, 48(2), 279-244. https://doi.org/10.1111/1467-9922.00041

Sugaya, N., \& Shirai, Y. (2007). The acquisition of progressive and resultative meanings of the imperfective aspect marker by L2 learners of Japanese: Transfer, universals, or multiple factors? Studies in Second Language Acquisition, 29(01), 1-38. https://doi.org/10.1017/s0272263107070015

Vendler, Z. (1957). Verbs and times. The Philosophical Review, 66, 143-160. https://doi. org/10.2307/2182371

Verkuyl, H. (1972). On the compositional nature of the aspects. Dordrecht, Germany: Reidel.

White, L. (1987). Against comprehensible input: The input hypothesis and the development of second-language competence. Applied Linguistics, 8(2), 95-110. https://doi.org/10.1093/ applin/8.2.95

Appendix

Exercises for Learning English Aspect (English version)

1. Let's compare the following Japanese verb groups. Focus on their meanings.

A. aru (be), iru (be), iru (need), dekiru (can do)

B. hashiru (run), oyogu (swim), asobu (play), yomu (read)
C. aku (open), tsuku (arrive), kowareru (break), shinu (die)

Q: Does each group of verbs have something in common?

2. Make a Japanese sentence using each verb.

A. $\quad$ aru (be) $\rightarrow \quad$ (e.g., Koen-ga aru. [There is a park.])

iru (be) $\rightarrow \quad$ (e.g., Inu-ga iru. [There is a dog.])

iru (need) $\rightarrow \quad$ (e.g., Okane-ga iru. [(I) need money.]

dekiru (can do) $\rightarrow \quad$ (e.g., Kare-wa Doitsugo ga dekiru.

[He can speak German.])

B. hashiru (run) $\rightarrow \quad$ (e.g., Senshu-ga hashiru. [The player runs.])

oyogu (swim) $\rightarrow \quad$ (e.g., Shonen-ga oyogu. [The boy swims.])

assobu (play) $\rightarrow \quad$ (e.g., Kodomotachi-ga asobu. [Children play.])

odoru (dance) $\rightarrow \quad$ (e.g., Shojo-ga odoru. [The girl dances.])

C. $\quad$ aku (open) $\rightarrow \quad$ (e.g., Doa-ga aku. [The door opens.])

tsuku (arrive) $\rightarrow \quad$ (e.g., Hikoki-ga tsuku. [The airplane arrives.])

kowareru (break) $\rightarrow$ (e.g., Kikai-ga kowareru. [The machine breaks.])

shinu (die) $\rightarrow \quad$ (e.g., Mushi-ga shinu. [An insect dies.])

Q: Does each group of verbs have something in common? Do they occur in a specific period of time?

3. Add -te iru to each sentence.

A. $\quad$ aru (be) $\rightarrow$

iru (be) $\rightarrow$

iru (need) $\rightarrow$

dekiru (can do) $\rightarrow$

(e.g., Koen-ga aru. $\rightarrow \times$ Koen-ga at-te iru.)

(e.g., Inu-ga iru. $\rightarrow \times$ Inu-ga it-te iru.)

(e.g., Okane-ga iru. $\rightarrow \times$ Okane-ga it-te iru.)

(e.g., Kare-wa Doitsugo ga dekiru.

$\rightarrow \times$ Kare-wa Doitsugo ga deki-te iru.)

B. hashiru (run) $\rightarrow$

(e.g., Senshu-ga hashiru. $\rightarrow$ Senshu-ga hashit-te iru.

[The player is running.])

oyogu (swim) $\rightarrow \quad$ (e.g., Shonen-ga oyogu. $\rightarrow$ Shonen-ga oyoi-de iru.

[The boy is swimming.]) 
asobu (play) $\rightarrow$

(e.g., Kodomotachi-ga asobu. $\rightarrow$ Kodomotachi-ga ason-de iru [Children are playing.])

odoru (dance) $\rightarrow$

(e.g., Shojo-ga odoru. $\rightarrow$ Shojo-ga odot-te iru. [The girl is dancing.])

C. $\quad$ aku (open) $\rightarrow$

(e.g., Doa-ga aku. $\rightarrow$ Doa-ga ai-te iru.

[The door is open.])

tsuku (arrive) $\rightarrow$

(e.g., Hikoki-ga tsuku.

$\rightarrow$ Hikoki-ga tsui-te iru. [The airplane arrived and is there.])

kowareru (break) $\rightarrow$ (e.g., Kikai-ga kowareru.

$\rightarrow$ Kikai-ga koware-te iru. [The machine is broken.])

shinu (die) $\rightarrow$

(e.g., Mushi-ga shinu.

$\rightarrow$ Mushi-ga shin-de iru. [An insect is dead.])

$\mathrm{Q}$ : What is the meaning of -te iru?
A: (N/A)
B: (progressive)
C: (resultative-state)

4. Find the English verb corresponding to each of the Japanese verbs.

A. aru: (e.g., be)

iru: (e.g., be)

iru: (e.g., need)

dekiru: (e.g., can do)

B. hashiru: (e.g., run)

oyogu: (e.g., swim)

assobu: (e.g., play)

odoru: (e.g., dance)

C. aku: (e.g., open)

tsuku: (e.g., arrive)

kowareru: (e.g., break)

shinu: (e.g., die)
5. Add -ing to each English verb and make a sentence.

A. (e.g., be $\rightarrow x)$

(e.g., need $\rightarrow x$ )

(e.g., can do $\rightarrow x$ )

B. (e.g., run $\rightarrow$ The player is running.)

(e.g., swim $\rightarrow$ The boy is swimming.)

(e.g., play $\rightarrow$ Children are playing.)

(e.g., dance $\rightarrow$ The girl is dancing)

C. (e.g., open $\rightarrow$ The door is opening.)

(e.g., arrive $\rightarrow$ The airplane is arriving.)

(e.g., break $\rightarrow$ The machine is breaking.)

(e.g., die $\rightarrow$ An insect is dying.)

$\mathrm{Q}$ : What is the meaning of -ing form?

A: (N/A) B: (progressive) C: (preliminary stage [reaching an end point])

6. Compare Japanese and English sentences. Do both -te iru and -ing have the same meaning?
Japanese -te iru
English -ing
A: (N/A)
A: (N/A)
B: (progressive)
B: (progressive)
C: (resultative-state)
C: (preliminary stage [reaching an end point])

7. Find more verbs for each verb group.
A:
B:
C:

8. Choose one verb from each English verb group and make a sentence. Then, translate it into Japanese. 